Article

\title{
Has Eurosceptic Mobilization Become More Contagious? Comparing the 2009 and 2014 EP Election Campaigns in The Netherlands and France
}

\author{
Maurits Meijers ${ }^{1, *}$ and Christian Rauh ${ }^{2}$ \\ ${ }^{1}$ Hertie School of Governance, 10117 Berlin, Germany; E-Mail: meijers@hertie-school.org \\ ${ }^{2}$ Research Unit Global Governance, WZB Berlin Social Science Center, 10785 Berlin, Germany; \\ E-Mail: christian.rauh@wzb.eu \\ * Corresponding author
}

Submitted: 1 October 2015 | Accepted: 8 January 2016 | Published: 29 February 2016

\begin{abstract}
With the lingering Euro crisis, personalized competition for the Commission presidency, and a surge of Eurosceptic parties, the 2014 European Parliament elections took place against an unknown level of European Union politicization. How does this changing context affect the supply side of party competition on European issues in EP election campaigns? This article compares the 2014 and 2009 EP elections in two EU founding members with high electoral support for radical left and radical right Euroscepticism - France and the Netherlands. We study publically visible patterns of partisan mobilization in the written news media with semi-automated content analyses. The data indicate that visible party mobilization on EU issues was on average not significantly higher in 2014. While particularly mainstream and especially incumbent parties publically mobilize on European issues during both campaigns, the radical right's mobilization efforts have become more visible during the 2014 elections. Examining the temporal dynamics within electoral campaigns, we show that the Eurosceptic fringes exhibit significant contagion effects on the mainstream parties, but that the extent of this contagion was surprisingly lower in the 2014 campaign. As a result, the increasing EU politicization between the 2009 and 2014 electoral contests has not resulted in an enhanced and more interactive supply of partisan debate about Europe.
\end{abstract}

\section{Keywords}

EP elections; EU politicization; Euroscepticism; partisan mobilization

Issue

This article is part of the issue "How Different Were the European Elections of 2014?", edited by Wouter van der Brug, Katjana Gattermann and Claes de Vreese (University of Amsterdam, The Netherlands).

(C) 2016 by the authors; licensee Cogitatio (Lisbon, Portugal). This article is licensed under a Creative Commons Attribution 4.0 International License (CC BY).

\section{Introduction}

Electoral accountability is key for the democratic quality of European integration. Yet, although the powers of the European Parliament (EP) have strongly increased in recent decades (Rittberger, 2012), the corresponding election campaigns are conventionally seen as 'secondorder' contests, during which political competition is mainly driven by domestic issues (Reif \& Schmitt, 1980). Yet, recent integration literature raises doubts on whether a key assumption of this model-that vot- ers ascribe little relevance to the EU-still holds. By contrast, observers from different camps note that the politicization of European issues is augmenting (De Wilde, 2011; Hooghe \& Marks, 2009; Hutter \& Grande, 2014; Rauh \& Zürn, 2014; Statham \& Trenz, 2013). These works show that the consecutive authority transfers from member-states to the EU have made European questions more salient and contested among the wider citizenry. Yet, has this societal politicization also been met by a greater supply of political debate about Europe, and has it affected the degree to which main- 
stream parties react to Eurosceptic challenger parties?

We approach this question by comparing the 2009 and 2014 EP election campaigns. In between these contests, the societal demand for political debate about Europe has arguably grown. European elites attempted to increase the consequentiality of the 2014 electoral contest with the 'Spitzenkandidaten' initiative (Hobolt, 2014). More importantly, the 2014 elections took place against the backdrop of the Euro crisis, which created high and sustained public salience of European issues over a period of almost five years. In addition, the increased electoral relevance of distinct anti-European parties stands out: in the run up to the 2014 EP elections Eurosceptics performed well in many national election polls.

To assess whether and how this changing context has affected the supply of public partisan debate on Europe, we examine the media coverage of the election campaigns in two EU founding states with significant national Eurosceptic challenger parties-France and the Netherlands. In modern 'audience democracies' (Manin, 1997) mass media constitute a crucial arena linking political elites and the wider electorate (e.g. de Vreese, 2001; Statham \& Trenz, 2013). Parties try to set the electoral agenda in this arena by making their preferred issues visible to the broader citizenry (Mazzoleni \& Schulz, 1999; Strömbäck, Maier, \& Kaid, 2011; Weaver, McCombs, \& Shaw, 2004). Hence, our research interest guides us to mediatized partisan mobilization efforts on European issues.

Using semi-automated procedures we retrieved cooccurrences of party actors and keywords for European issues in a large corpus of articles published in six French and Dutch newspapers in the seven weeks preceding each EP election. Based on this data we, first, study the supply of European issues by Eurosceptic challengers and mainstream parties during and across both EP campaigns. Second, we assess temporal contagion effects of mediatized Eurosceptic mobilization on publically visible mainstream party emphasis of $\mathrm{EU}$ issues.

The article is structured as follows. We first discuss the changing context of EP elections before deriving detailed expectations from the literature on partisan competition and mediatization. The subsequent section details our empirical strategy. Then, after presenting our findings, we summarize the major implications in the concluding section. The analyses show that the degree of publically visible partisan mobilization efforts on European issues was on average not significantly higher during the 2014 EP campaign. Whereas particularly incumbent parties made European issues visible in both periods, parties from the radical right stepped up their mobilization efforts during the 2014 campaigns in France and Netherlands. The Eurosceptic radical right exhibit significant contagion effects on mainstream party emphasis of European issues in the short-run, but the extent of this contagion was, surprisingly, lower in the 2014 campaign. The results suggest that the potentially higher salience of EU issues among the electorate is not met by a growing and more interactive supply of corresponding partisan debate.

\section{EP Elections in Context: EU Politicization and Mediatization}

Since the seminal work of Reif and Schmitt (1980) on the first direct EP election, these electoral contests have often been described as 'second-order' elections. The second-order model attributes the low voter turnout as well as the gains of smaller parties and the losses of national incumbents during EP elections to a lack of interest on part of the electorate (Marsh \& Mikhaylov, 2010, p. 13; Reif \& Schmitt, 1980, p. 9). Since voters are assumed to ascribe little political relevance to the EU and the EP in particular, the model expects that voters use EP elections mainly to punish their domestic governments. Respective partisan campaigns should thus primarily invoke domestic conflicts rather than revolving around European issues (Van der Brug \& Van der Eijk, 2007; Van der Eijk, Franklin, \& Marsh, 1996).

Yet, the view that EP elections lack European content has received a couple of dents over the course of integration. There is evidence that individual vote choices during more recent EP elections are driven by individual preferences on European issues (Hobolt, Spoon, \& Tilley, 2009; Rohrschneider \& Clark, 2008). Moreover, EP elections in younger EU member states display a lower degree of protest votes against incumbent governments (Koepke \& Ringe, 2006). And most importantly, parties with clear-cut, outspoken positions on European integration tend to fare better in more recent European elections (Hix \& Marsh, 2007, p. 503; Ferrara \& Weishaupt, 2004).

Such findings qualify the expectation that EP election campaigns are not about Europe at all. Moreover, they are in accordance with recent works that attest to a growing EU politicization defined broadly as 'an increase in polarization of opinions, interests or values and the extent to which they are publicly advanced towards policy formulation within the EU' (De Wilde, 2011). Such perspectives argue that the extension of supranational political authority over the consecutive EU treaty revisions have triggered sustained societal demands for more political debate on European issues (De Wilde \& Zürn, 2012; Rauh, 2015). Others claim that it is the increased relevance of national identity conflicts that raises the public contentiousness of European questions (Kriesi et al., 2012). In any case, EU politicization implies that European 'decision making has shifted from an insulated elite to mass politics' (Hooghe \& Marks, 2009, p. 13). Against this backdrop, recent EP elections provide a window of opportunity for political entrepreneurs willing to profit from mobilizing on European questions (Treib, 2014). 
To assess whether this context offers voters more debate on Europe, a focus on media coverage of EP election campaigns is crucial. Public media play a central role in the way modern democracies function (Mazzoleni \& Schulz, 1999; McCombs \& Shaw, 1972), since it is only in the public sphere that latent societal conflicts become manifest and alternative political choices are revealed (Koopmans \& Statham, 2010, p. 44; Meijers, 2013, p. 3). Particularly during election campaigns, the media constitute the central arena in which parties can offer political alternatives to voters (Strömbäck et al., 2011). Just as parties compete over which issues are on the political agenda (Carmines \& Stimson, 1986; Schattschneider, 1960), they also engage in a struggle over the visibility of 'their' issues and positions in the public sphere (Koopmans, 2004, p. 373).

With regard to European integration, Van Spanje and de Vreese (2014) argue that media evaluations of the European Union influenced vote choices in the 2009 EP election (see also Vliegenthart, Schuck, Boomgaarden, \& de Vreese, 2008). Similarly, Hobolt and colleagues find that a Eurosceptic tone in the media coverage of an EP campaign spurs the level of voter defection from mainstream parties (Hobolt et al., 2009). More generally, the extant literature demonstrates that media visibility matters for the electoral fortunes of parties (Dalton, Beck, \& Huckfeldt, 1998; Hopmann, Vliegenthart, De Vreese, \& Albæk, 2010)especially for challengers propagating new issues on the electoral map (e.g. Koopmans \& Muis, 2009; Vliegenthart, Boomgaarden, \& Van Spanje, 2012; Walgrave \& De Swert, 2004). In sum, mediatized partisan mobilization on European issues is in fact consequential for voters' preferences.

Unsurprisingly, most recent studies of EU-related partisan mobilization focus therefore on mediatized conflicts (Hutter \& Grande, 2014; Kriesi et al., 2008, 2012; Statham \& Trenz, 2013). But not all purposive mobilization efforts of political parties-as for example expressed in speeches, manifestos or press releaseswill make it onto the media agenda (Hopmann, Van Aelst, \& Legnante, 2012). Since the seminal work by Galtung and Ruge (1965) we know that journalists and editors act as gatekeepers. Competitive pressures and space constraints in media outlets lead to a selective coverage of political developments. Whether the media consider a particular event 'newsworthy' will depend, among other things, on the expected relevance of the action for the medium's primary audience, on the level of conflict associated with the event, on the possibilities for dramatization and personalization, as well as on the perceived standing of the involved actors (Galtung \& Ruge, 1965, pp. 65-72). When assessing the supply side of publically visible partisan debate on Europe, such media logics have to be taken into account. Yet, media actors still can ultimately only select from the menu of mobilization efforts that political parties offer. Moreover, during election periods political parties exert particular influence on the media agenda rather than the other way around (e.g. Brandenburg, 2002; Walgrave \& Van Aelst, 2006).

\section{Theorizing Mediatized Partisan Mobilization Efforts in Recent EP Campaigns}

The political developments between the 2009 and 2014 EP campaigns have arguably amplified such politicization and mediatization dynamics. First, between 2009 and 2014 the Greek deficit turned into a fullfledged European financial and monetary crisis. The numerous supranational emergency measures and their immense inroads into national budgetary autonomy have made supranational authority clearly tangible for the wider European publics - thereby spurring the societal politicization of European integration to an unprecedented degree (Rauh \& Zürn, 2014). Second, European elites from the European Commission and particularly the European Parliament sought a more proactive approach in the run-up to the 2014 election. The 'Spitzenkandidaten' initiative, in which each of the EP's major political groups selected a common lead candidate, aimed to increase the perceived consequentiality of the elections (Hobolt, 2014).

For political parties, this should have signalled a higher salience of European questions among the electorate, which in turn creates incentives to emphasize European issues for electoral reasons. For media gatekeepers, it should have signalled a higher relevance of European issues among readers and more conflict potential among political elites, which increases news value. Hence both from a partisan competition as well as from mediatization perspective it can be expected that:

H1.1: The degree of publically visible partisan mobilization efforts on European issues in EP election campaigns is higher in 2014 than in 2009.

This effect will hardly be uniform across all parties, however. From a party competition perspective, saliency theory (Budge, 1982; Dolezal, Ennser-Jedenastik, Müller, \& Winkler, 2014) underlines that parties do not only compete on particular positions but also on which issues to emphasize in the first place (Carmines \& Stimson, 1986; Schattschneider, 1960). Here it is conventionally assumed that mainstream parties downplay European issues, since they are faced with more diverse opinions among their constituencies and cannot map European issues easily on the domestically dominating left-right dimension (de Vries, 2007; Statham \& Trenz, 2013; Van der Eijk \& Franklin, 2004). In contrast, smaller anti-European parties can afford to or even profit from firmly rejecting the integration project (de Vries \& Edwards, 2009; Hobolt \& de Vries, 2015; Van de Wardt, de Vries, \& Hobolt, 2014). 
However, this constellation does not necessarily hold during mediatized EP election campaigns. When voter attention is at least partially directed to European questions, incumbent parties, in particular, may see themselves as being forced to address these issues as they accrue from their governmental responsibility and their participation in Brussels' decision-making. In addition, mainstream parties that hold or expect to hold governmental responsibility might consider that 'tying their hands' in front of national publics creates bargaining advantages at the supranational level (Bailer \& Schneider, 2006). In other words, mainstream and particularly incumbent parties face electoral incentives to justify and defend their past and future actions in Brussels (cf. Braun, Hutter, \& Kerscher, 2015; Rauh, 2015; Senninger \& Wagner, 2015).

From a mediatization perspective, moreover, not all political parties have equal chances to place their preferred issues on the media agenda (Brandenburg, 2002; Hopmann, Elmelund-Praestekaer, Albaek, Vliegenthart, \& de Vreese, 2012; Tresch, 2009). Since Galtung and Ruge's (1965) original argument on the positive effect of an actor's political standing on the news value of corresponding events, it has repeatedly been shown that both party size and political power affect the degree of partisan media coverage (e.g. GreenPedersen, Mortensen, \& Thesen, 2015; Hopmann, de Vreese, \& Albaek, 2011; Tresch, 2009). In particular, whether a party is in government or not substantially affects its presence in the news (Brandenburg, 2005; Green-Pedersen et al., 2015; Hopmann et al., 2011; Schoenbach, De Ridder, \& Lauf, 2001). We expect this to also hold for the EP election campaigns (see also Jalali \& Silva, 2011). Again, strategic partisan incentives and media logic arguments arrive at similar expectations:

\section{H1.2: During EP election campaigns, mainstream parties' mobilization efforts on European issues are more visible than those of smaller radical parties.}

\section{H1.3: During EP election campaigns, governing} parties' mobilization efforts on European issues are more visible than those of opposition parties.

But also with regard to selective partisan emphasis, the politicization argument developed above predicts substantial differences between the 2009 and 2014 EP elections. The Eurocrisis and the 'Spitzenkandidaten' initiative present specific issue ownership advantages for both radical right and radical left parties, which likely motivates these parties to place 'their' European issues on the media agenda. First, redistributing large amounts of national funds to other EU member-states and the indirect election of the Commission president signal strong steps towards further political integration. This is likely to foster Eurosceptic mobilization by the radical right on the basis of their traditional sovereign- ty-related arguments 'against Europe'. Second, the supranational emergency responses to the Euro crisis strongly emphasised austerity politics. This should serve the mobilization of EU-related socio-economic questions along the traditional arguments of the radical left (de Vries \& Edwards, 2009). To the extent that the Eurosceptic fringes exploit this mobilization potential, they confront their mainstream contenders. Such conflict, in turn, increases the news value from the perspective of media gatekeepers. We thus expect that:

H1.4: Mobilization efforts on European issues by radical right and radical left parties are more visible in the EP Elections in 2014 than in the 2009 campaign.

Yet, a sole concentration on selective partisan emphasis seems too static. Election campaigns should also be regarded as dynamic processes (Brandenburg, 2002, p. 40). The literature on partisan competition argues that mainstream parties do not only devise their strategies in the face of changing public opinion, but also react to other parties' behaviour (Adams, 2012). Challenger parties, which open new dimensions of political competition, can provoke mainstream reactions-both in terms of positional changes as well as issue emphasis adaptations (Bale, Green-Pedersen, Krouwel, Luther, \& Sitter, 2010; Hobolt \& de Vries, 2015; Meguid, 2005; Van Spanje, 2010). ${ }^{1}$

Recent work on the topic shows that the success of Eurosceptic radical parties, both from the radical left and radical far right, is capable of influencing mainstream parties to tone down their overall support for European integration (Meijers, 2015). Moreover, Van de Wardt (2015) shows, for the case of Denmark, that parliamentary activities of challenger parties on European integration provoke salience shifts by mainstream parties. Thus, given the higher salience and higher polarization of European issues among the wider electorate, mainstream parties should have an incentive to react to publically visible mobilization efforts from their Eurosceptic challengers.

But the literature on party emphasis of EU issues has so far mainly focused on highly aggregated crossnational comparisons or extended time frames (De Wilde, 2010; Höglinger, 2012; Hutter \& Grande, 2014). We assert that our understanding of Eurosceptic contagion is improved by also analysing the micro-level dynamics within mediatized election campaigns. This is of particular relevance here because the news media are prone to cover dynamic, conflictual relationships

\footnotetext{
${ }^{1}$ It is also possible that challenger parties react to mainstream party behaviour (see Van de Wardt, 2015). Yet, since mainstream parties are the ones that hold office and, ultimately, control the decision-making process the literature has focused on the impact of fringe parties on the established political forces.
} 
(Galtung \& Ruge, 1965). Analogous to the aggregate findings on responsive partisan behaviour, we also expect contagion effects to be visible in the news media:

H2.1: The more mobilization efforts on European issues from radical left and the radical right parties are visible at time $t-1$, the more mainstream party emphasis of European issues is visible at time $t$.

Such contagion is, however, unlikely to be constant across Eurosceptic parties. The different camps oppose European integration on fundamentally different grounds. The radical right rejects the EU on the basis of identity and sovereignty concerns, while the radical left rejects the EU on the basis of its ingrained marketliberal policies (de Vries \& Edwards, 2009). In line with arguments that party competition over cultural issues is becoming more salient (Hooghe \& Marks, 2009; Kriesi, 2007), Meijers (2015) has shown that the 'contagion effect' of Eurosceptic success was stronger for the radical right than for the radical left. The radical right's cultural arguments against Europe do not only influence the centre-right, but can also provoke accommodative reactions from the centre-left parties (cf. Van Spanje, 2010). The reason is that the traditional supporters of the centre-left-the working-class-are likely to adhere to more culturally conservative stances as well (Bale et al., 2010). Radical left critiques of a 'neoliberal' bias in the integration process, in contrast, may be co-opted by the centre-left (Statham \& Trenz, 2013, p. 139) but are unlikely to strike a chord among the centre-right. Hence, mobilization of European issues from the radical right should be more contagious for mainstream parties than similar efforts from the radical left.

Also from a media perspective it is to be expected that mediatized radical right mobilization is more capable of affecting the level of visible mainstream party EU issue emphasis. In particular the Dutch and the French radical right parties are 'media savvy' because they rely on a strongly personalized leadership and a highly confrontational political style (Mazzoleni, 2007; see also de Lange \& Art, 2011). The radical left, on the other hand, is more fragmented and generally characterized by less conspicuous leadership-at least in the French and Dutch cases. Hence, we expect that:

H2.2: The effect of visible radical right mobilization on European issues at time $\mathrm{t}-1$ on mediatized mainstream party mobilization on EU issues at time $t$ is greater than the effects of visible radical left EU mobilization.

The extant literature has furthermore emphasized that contagion effects depend on both the electoral support of radical parties and their anticipation of electoral advantages by raising the salience of European issues
(Meijers, 2015). Following the above arguments on the increasing public politicization of European integration between 2009 and 2014, we argue that both the electoral strength of challenger parties and their possible gains from raising European issues further should have grown during the Eurocrisis and the 'Spitzenkandiaten' initiative. Indeed, polls at the beginning of the campaigns show that Eurosceptic challengers could have expected large gains in the 2014 elections. $^{2}$ From a media perspective, more electoral support increases the political standing and the audience relevance of these challenger parties. Thus, we finally expect that:

H2.3: The contagion effect of visible radical left and radical right EU mobilization on mainstream parties is greater in the 2014 than in the 2009 campaign.

\section{Data and Methods}

The theoretical discussion guides the case selection to EU member states with sizeable electoral support for Eurosceptic radical parties on both extremes of the political spectrum. We therefore focus on France and the Netherlands. Both countries are founding members of the European Communities and share a comparable history of being subject to supranational authority. In both countries, Eurosceptics from both sides have been relatively successful in recent years. Moreover, Eurosceptic mobilization in both countries has repeatedly affected the progress of European integration, most notably with the popular rejection of the Constitutional Treaty in 2005. This makes France and the Netherlands apt cases to study the public supply of partisan mobilization on Europe.

We cover the main Eurosceptic parties as well as the principal centre-left and centre-right mainstream parties in these countries (see Table 1). Since the French radical left is traditionally very fragmented, four political parties are included in this group. Since our hypotheses compare publically visible mobilization efforts of mainstream parties, which regularly alternate in government, with radical Eurosceptic mobilization attempts, a number of smaller parties, such as MoDem in France and the D66 in the Netherlands, have not been included. Although these parties have enjoyed noteworthy successes in EP elections, they represent minor domestic political forces and cannot be easily dichotomized into the mainstream-challenger distinction.

\footnotetext{
2 For Dutch election polls from April 2014, see http://www.tnsnipo.com/nieuws/persberichten/d66-leidt-landelijk,-pvv-ineuropa (accessed September 23, 2015). For French election polls from May 2014 see http://tnova.fr/sondages/exclusifsondage-ipsos-steria-pour-le-monde-le-cevipof-et-terra-novaelections-europeennes-2014-barometre-quotidien-dintentions-de-vote-18-mai (accessed September 24, 2015).
} 
Table 1. List of parties included in the analysis.

\begin{tabular}{lccrrr} 
& \multicolumn{2}{c}{ Mainstream parties } & & \multicolumn{2}{c}{ Radical parties } \\
\cline { 2 - 3 } & Centre-left & Centre-right & & Radical Left & Radical Right \\
\hline France & PS $(+)$ & UMP (\#) & & PdG; PCF; LO; LCR/NPA & Front National \\
The Netherlands & PvdA $(\#+)$ & CDA (\#); VVD $(+)$ & & SP & PVV \\
\hline
\end{tabular}

Note: parties marked with (\#) and (+) were incumbents in 2009 and 2014, respectively.

Our analyses rely on an original dataset that captures the co-occurrences of these political parties and European integration issues during the 2009 and 2014 European Parliament election campaigns in the French and Dutch written news media. The newspaper selection follows Koopmans and Statham (2010, p. 51). It covers Le Monde and De Volkskrant as the major leftleaning and Le Figaro and Algemeen Dagblad as the major right-leaning newspapers in France and the Netherlands respectively. Since neither country has a typical tabloid paper, we take L'Humanité and De Telegraaf as the most similar substitutes (Koopmans \& Statham, 2010).

Through this diverse newspaper sample we at least implicitly control media selection effects due to varying outlet audiences. But we have to note that the Dutch and French media systems differ (Hallin \& Mancini, 2004). The decreasing state influence on the media in the Netherlands is contrasted by the bi-partisan divide in the French print media and the strong ties the media has with the French government. We thus expect that political reporting in general and particularly the predominance of mainstream and incumbent parties is more pronounced in the French case (cf. H1.2 and H1.3). Note, however, that our hypotheses do not predict cross-national differences but solely address differences across parties and election campaigns within countries.

The analyses rely on the daily issues of these newspapers during the hot phase of each campaign in the seven weeks before each election day. We identified relevant articles in the LexisNexis database by specific search strings requiring that an article (in headline or body) contain at least one keyword relating to the partisan actors in question and at least one keyword indicating an issue about European integration (see Appendices $\mathrm{A} 1$ and $\mathrm{A} 2$ for the full lists). These keywords were identified with reference to the codebooks from previous studies (Hutter \& Grande, 2014; Koopmans, 2002; Rauh, 2015) and include inflections commonly used in the French and Dutch languages. In total, we examine 6,174 newspaper articles from six major newspapers in four seven-week periods preceding the elections.

Automated scripts store these raw text data in data frames with one time stamped observation per article. From each observation, we then automatically retrieved all sentences that contained at least one European integration keyword and then assessed whether a specific party group was also mentioned in this re- duced textual data. For each article we thus capture whether a centre-left, centre-right, radical left or radical right actor occurred at least once within a grammatical sentence that also contains a keyword on European integration.

We take such co-occurrences as a proxy for publically visible incidences of partisan efforts to mobilize on European integration. It seems plausible that if a party takes a newsworthy stance on a European issue on a given day, this will be reflect at least once in a journalistic sentence that includes both the party and the EU marker. A cursory overview of our actual hits in the newspaper corpus confirms that this is by and large true. The overview indicates a few false positives where journalists ascribe some link between a party and an EU issue without actual partisan action. The counts thus slightly overestimate partisan mobilization, which, however, should affect all party groups alike. This is further bolstered by systematically comparing our data with hand-coded data collection efforts of the first author in an earlier project on the 2014 elections. We find positive and significant correlations between our automatically retrieved counts and these manually identified data across party groups and countries. ${ }^{3}$ In sum, our measure adequately corresponds to partisan mobilization efforts on European issues.

This data was finally aggregated to the daily level. Accordingly, the unit of analysis is the number of articles per party and day in which at least one incidence of party mobilization on Europe is observed. This allows comparisons across party groups and election periods needed for hypotheses 1.1-1.4. For the contagion effects hypothesised in $\mathrm{H} 2.1-2.3$, the dependent variable is operationalized as the total number of articles per day in which mainstream party actors appear in the immediate context of European integration. The independent variables are an incumbency dummy as well as the number of co-occurrences of radical left or radical right actors and EU issues, lagged by one day.

Our estimations thus deal with discrete, nonnegative values. The data, in addition, is highly overdispersed meaning that the variance of the count variables exceeds their mean (see Appendix A4). This is common for event counts where many observations have a value of zero, but it violates the assumption of

\footnotetext{
${ }^{3}$ The manually and automatically retrieved counts of partisan mobilization efforts correlate on average with .4 (396 party/day observations). For more detailed comparisons across countries and party groups see Appendix A3.
} 
statistical independence in the observed events and can inflate coefficient significance. To study contagion effects, we thus employ negative binomial regression models which include a parameter that reflects the unobserved heterogeneity in the observations (Long \& Freese, 2001, p. 243). The data is structured as a panel, with 'days' being the time variable and 'party' the cross-sectional identifier. ${ }^{4}$ To address serial correlation issues, a lagged dependent variable has been included in each model. In order to be able to control incumbency effects explicitly, we estimate random effects models and check robustness of our findings also for a partisan fixed effects model (Appendix A5).

${ }^{4}$ Since the data is made up of consecutive days, the panels are strongly balanced. For the Netherlands the number of daily observations is slightly lower since none of the analysed newspapers are published on Sundays.

\section{Empirical Results}

Figure 1 plots the mean daily count of publically visible partisan mobilization on European issues with bootstrapped 95 per cent confidence intervals. In view of the increased public politicization during the Euro crisis and the new procedure of binding the Commission president to EP election results, we had initially expected that the average aggregate levels of partisan mobilization on European issues would be higher in 2014 than in 2009. The daily counts of mediatized mobilization on European issues across all parties in Figure 1 have slightly heightened from 1.65 to 1.8 in France and from 0.45 to 0.52 in the Netherlands. But since these differences are negligible and far from reaching statistical significance, Hypothesis 1.1 is not supported in our data.

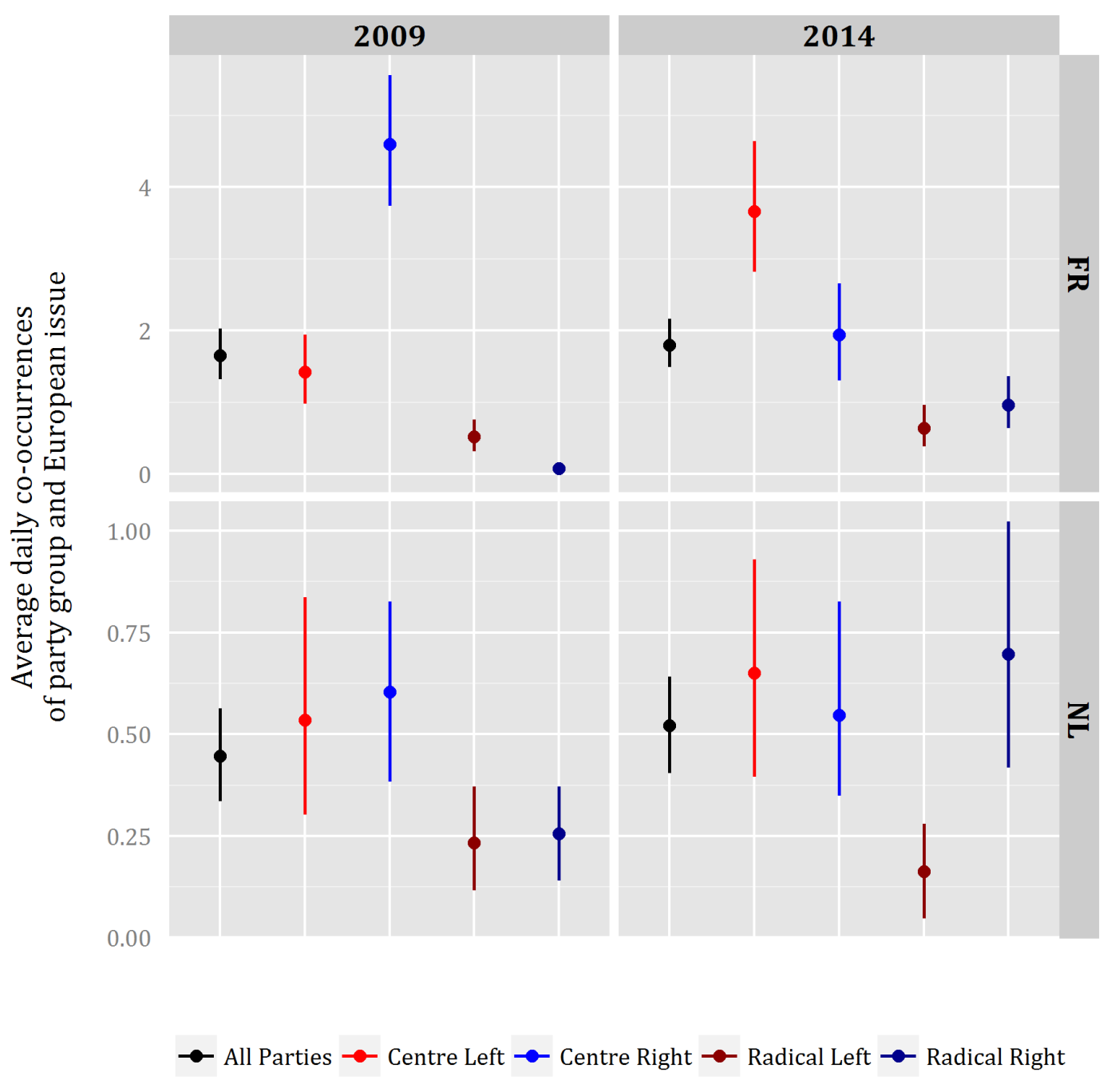

Figure 1. Average daily co-occurrences of party groups and European issues. Note: the scales for the Netherlands and France differ for presentation purposes. 
How does this picture differ across party groups? In contrast to the traditional expectation that mainly fringe parties mobilize on European issues (de Vries, 2007; Statham \& Trenz, 2013; Van der Eijk \& Franklin, 2004), our hypotheses 1.2 and 1.3 predicted that mainstream and particularly incumbent parties have greater incentives as well as greater chances to mobilize European issues in the public media (e.g. Hopmann et al., 2011). This expectation is fully confirmed for France in the upper panel of Figure 1-in the media coverage of both election campaigns, the centre-left and the centre-right are associated with European issues much more frequently than their radical counterparts. This data also underlines the hypothesized incumbent effect. Mobilization efforts by the UMP, the centre-right governing party during Sarkozy's presidency, were particularly visible in the 2009 campaign. In 2014, the roles reversed and the daily EU mobilization efforts by the then governing centre-left PS became predominant. Hence, the higher visibility of the centre-left in France is an incumbency effect. The French case thus confirms our expectations that mainstream and especially incumbent parties publically mobilize on Europe.

In the Netherlands (lower panel of Figure 1), the mean level of centre-right and centre-left mobilization efforts on European issues also clearly exceeds the observed levels for the radical challenger parties in 2009. However, compared to the French case, the overall picture is less clear-cut. First, conclusions about the incumbency effect are hampered by the fact that the centre-right category comprises both the Christian democrats (CDA) and the conservative liberals (VVD), which were in government only in 2009 or 2014, respectively. We thus treat these parties separately in the regression analyses below. Second, in 2014 the mean daily EU mobilization efforts by the radical right party (PVV) exceed the levels of mainstream mobilization efforts, though this difference is not statistically significant. ${ }^{5}$

The observed surge of the public EU mobilization efforts by the PVV in 2014 points to the expectation that the increased politicization of European integration between the 2009 and 2014 elections created favourable opportunity structures to mobilize European issues for the radical Eurosceptic parties (H1.4). But the radical left mobilization of European issues did not significantly change across the two election campaigns.

\footnotetext{
${ }^{5}$ The fact that our findings on these hypotheses diverge across both countries is consistent with literature showing that uneven power distributions among political parties in national systems is mirrored in differing mobilization potentials (e.g. Schoenbach et al., 2001). In the highly uneven, presidential system in France, incumbent parties enjoy distinct advantages in terms of mobilization potentials. On the contrary, the Dutch proportional representation system, where political power is more equally distributed, seems to produce more equitable arenas for public mobilization efforts.
}

This echoes claims that the Euro crisis did not offer opportunities for fundamentally re-thinking the structure of the European economy (Schmidt \& Thatcher, 2013). Moreover, the finding that the radical left was not able to mobilize significantly more resonates well with the view that cultural aspects of European integration have become more pervasive than socio-economic conflicts (Hooghe \& Marks, 2009; Meijers, 2015).

And indeed, the data demonstrate that visible radical right EU mobilization in the 2014 campaign is higher than in 2009 and that this difference is statistically significant. In the media coverage of the 2009 French election campaign, the radical right was associated with European issues on average only 0.16 times a day. In 2014, this surged to a daily average of 0.96 publically visible mobilization efforts from the radical right. Expressed differently, while the media coverage of the French 2009 campaign supplied radical right stances on Europe only on roughly every sixth day, such signals increased to an almost daily frequency in 2014. Similarly, in the Netherlands the higher degree of average daily radical right mobilization efforts on Europe is also sizeable and statistically significant (from 0.25 daily counts in 2009 to 0.7 in 2014). As shown, this extended visibility of the Dutch radical right's mobilization efforts on Europe even surpasses the levels of their major national mainstream competitors in the most recent EP election campaign. In line with hypothesis 1.4, thus, this suggests that both Le Pen's Front National and Wilders' PVV used the politicized context of 2014 elections much more strongly to publically communicate their stances on actual European questions. But has this increased Euroscepticism from the radical right also become more contagious for other actors in the debate?

To tackle this question, we now focus on our hypotheses addressing the micro-level dynamics within electoral campaigns. The results of the negative binomial regression analyses are reported in Table 2. Rather than the originally estimated logarithm of the expected event count, we report exponentiated coefficients in this table. These figures express the more straightforward incidence rate ratios. That is, they show how one unit increase in the independent variables (radical left and radical right mobilization at $\mathrm{t}$ 1 as well as incumbency) affects the rate by which the event of interest-publically visible mainstream mobilization efforts on European issues-occurs. Hence, values below 1 signal a negative relationship and values above 1 a positive relationship. This standardization allows us to compare effect sizes across models. ${ }^{6}$

\footnotetext{
${ }^{6}$ Since the standard errors of the exponentiated coefficients are not meaningful, the standard errors of the regular negative binomial regressions coefficients are reported. This does not affect the significance of the results, since the associated tvalues are identical.
} 
Table 2. Negative binomial panel regression results.

\begin{tabular}{|c|c|c|c|c|}
\hline & \multicolumn{4}{|c|}{ Daily co-occurrences of Mainstream parties and EU issues } \\
\hline & \multicolumn{2}{|c|}{ France } & \multicolumn{2}{|c|}{ The Netherlands } \\
\hline & 2009 & 2014 & 2009 & 2014 \\
\hline & Model 1 & Model 2 & Model 3 & Model 4 \\
\hline \multirow[t]{2}{*}{ Lagged DV (t-1) } & 1.024 & $1.053^{+}$ & 0.835 & 1.096 \\
\hline & $(0.0288)$ & $(0.0286)$ & $(0.194)$ & $(0.100)$ \\
\hline \multirow[t]{2}{*}{ EU Statements Rad. Left (t-1) } & 1.163 & $1.140^{*}$ & 0.630 & 1.167 \\
\hline & $(0.100)$ & $(0.0598)$ & $(0.384)$ & $(0.289)$ \\
\hline \multirow[t]{2}{*}{ EU Statements Rad. Right (t-1) } & $2.256^{* *}$ & $1.159^{*}$ & $2.215^{*}$ & $1.381^{*}$ \\
\hline & $(0.223)$ & $(0.0672)$ & $(0.325)$ & $(0.127)$ \\
\hline \multirow[t]{2}{*}{ Incumbent } & $3.083^{* *}$ & $1.792^{* *}$ & 0.743 & $2.023^{*}$ \\
\hline & $(0.212)$ & $(0.188)$ & $(0.301)$ & (0.339) \\
\hline \multirow[t]{2}{*}{ Constant } & 1.139 & 1.030 & 0.775 & 0.599 \\
\hline & $(0.349)$ & $(0.313)$ & $(0.447)$ & $(0.589)$ \\
\hline No. observations & 98 & 98 & 126 & 126 \\
\hline No. of Days & 49 & 49 & 42 & 42 \\
\hline Wald $\mathrm{Chi}^{2}$ & $60.11 * *$ & $46.70 * *$ & $8.01^{+}$ & $15.48 * *$ \\
\hline Log likelihood & -195.95 & -199.26 & -128.21 & -124.67 \\
\hline
\end{tabular}

Note: exponentiated coefficients (Incidence rate ratios); Standard errors in parentheses; ${ }^{+} p<0.10,{ }^{*} p<0.05,{ }^{* *} p<0.01$.

The results for France in the left panel of Table 2 show that the overall rather limited mobilization efforts on EU issues from the radical left also triggered only limited responses from the mainstream parties. In 2009 the effect fails to reach statistical significance, in 2014 radical left statements at $\mathrm{t}-1$ raise the propensity of mainstream party EU mobilization by 14 per cent at $t=0$. The contagion effects of the French radical right, in contrast, are more sizeable and statistically robust. In 2009, Front National statements on European issues made mainstream party EU statements almost 2.3 times more likely on the subsequent day. Robust contagion effects from the radical right can also be shown for the 2014 election in France, but their absolute size declined to, approximately, 16 percentage points.

In the Dutch campaigns, we find no significant contagion effects from the radical left. But like the French cases, the Dutch radical right was also able to spur mainstream party reactions by its EU mobilization while the size of this contagion effect declined as well. In 2009, mediatized radical right mobilization efforts on EU issues at $t-1$ substantially affect co-occurrence of mainstream parties and EU issues on the following day, increasing the expected number of corresponding counts by more than 120 percentage points. In 2014, this contagion effect of radical right mobilization on European issues is still significant but amounts to only 38 percentage points. ${ }^{7}$

Besides the fact that our respective control variable largely confirms expectation that particularly parties in

\footnotetext{
${ }^{7}$ We have additionally estimated reversed models in order to detect whether there is a reciprocal relationship between mainstream and challenger moiblization efforts. These are reported in Table A6.1 in the appendix. Only for the Netherlands in 2014 was such a reciprocal effect found.
}

government are associated with EU issues in the media (H1.3), the models contradict claims that radical parties have no leverage over the extent to which mainstream parties address European issues (Green-Pedersen, 2012; Hutter \& Grande, 2014). In line with our hypotheses 2.1 and 2.2 we demonstrate cross-temporal contagion effects, and as expected in extant research they are much more pronounced for the radical right than for the radical left (Bale et al., 2010; Meijers, 2015; Van Spanje, 2010). Much to our surprise, however, the higher public salience of EU issues during the period of the seventh European Parliament has not strengthened these contagion effects as suggested by $\mathrm{H} 2.3$. While radical right contagion remained significant, its absolute size declined if we compare the 2014 EP election campaign to the 2009 campaign. Thus an increased societal EU politicization does not automatically translate into a more interactive partisan debate about EU issues (Rauh \& Zürn, 2014).

\section{Conclusions}

At first sight, our systematic comparisons of mediatized partisan mobilization efforts on European issues during the French and Dutch EP election campaigns in 2009 and 2014 result in a complex picture. Most importantly, the overall publically visible partisan debate on European issues was not significantly higher in the 2014 campaign. Distinguishing different party groups, we observe a rather stable dominance of mainstream and particularly incumbent parties. The major change from the 2009 to the 2014 EP elections in both countries, however, is a clearly heightened visibility of radical right mobilization efforts on European issues. Yet, this has not increased the responsiveness of mainstream parties as the analysis of cross-temporal contagion ef- 
fects underlines. To be sure, we demonstrate significant short-term contagion from the fringes of the party spectrum to the mainstream parties across both countries and elections, but the size of these contagion effects has manifestly declined from the 2009 to the 2014 EP election campaigns.

This article has provided innovative and robust findings with regard to the inter-party dynamics and patterns of parties' mobilization efforts during mediatized EP election campaigns. It is unclear, however, to what extent these patterns of visible mobilization are mediated by the type of EU issue. Future research should take this into account when examining the inter-party dynamics in EP campaigns. Moreover, the data presented draws on aggregated visibility levels from quality and non-broadsheet newspapers and has not focused on the tone of the news articles in question. Hence, the extent to which outlet type and the characteristics of the news coverage affect patterns of visible party competition should be further explored. Moreover, future research efforts should ascertain whether the patterns found for France and the Netherlands are generalizable to other EU member states.

Nevertheless, with respect to electoral accountability in EP elections, our analysis of the supply side of political debate on Europe in member-states with high support for Eurosceptics should be enough to stir normative concern. While European questions have become much more salient for the wider citizenry between the 2009 and 2014 EP election campaigns (Rauh \& Zürn, 2014), our data show that the partisan supply of political alternatives or justifications on European issues has not followed suit. Despite the profound socio-economic repercussions of the Eurocrisis and despite the attempt to increase the consequentiality of the vote choice by installing lead candidates, neither the radical left nor most mainstream parties seemed willing or able to step up their mobilization game on European issues in the 2014 electoral contests. The fact that the French centre-left did emphasize EU issues more is best explained by the incumbency effect rather than heightened purposive EU issue emphasis. As such, the mobilization potential has apparently been left to radical right parties that oppose supranationalization on cultural grounds.

Thus, increased radical right mobilization in conjunction with the declining contagion effects on mainstream parties suggests that the 2014 EP elections in France and the Netherlands did not result in a broader publically visible and more interactive debate about European issues. In this light, the most recent election campaigns for the European Parliament hardly provided an effective antidote to citizen alienation from common political decision-making in Europe.

\section{Acknowledgments}

An earlier version of this article was presented at the 22nd International Conference of Europeanists at Sciences Po in Paris, July 8-10, 2015. We moreover appreciate the valuable and constructive comments by the special issue editors and two anonymous reviewers. Replication data is available at the authors' websites.

\section{Conflict of Interests}

The authors declare no conflict of interests.

\section{References}

Adams, J. (2012). Causes and electoral consequences of party policy shifts in multiparty elections: Theoretical results and empirical evidence. Annual Review of Political Science, 15(1), 401-419.

Bailer, S., \& Schneider, G. (2006). Nash versus Schelling? The importance of constraints in legislative bargaining. In R. Thomson, F. N. Stokman, C. H. Achen, \& T. König (Eds.), The European Union decides (pp. 153177). Cambridge: Cambridge University Press.

Bale, T., Green-Pedersen, C., Krouwel, A., Luther, K. R., \& Sitter, N. (2010). If you can't beat them, join them? Explaining social democratic responses to the challenge from the populist radical right in Western Europe. Political Studies, 58(3), 410-426.

Brandenburg, H. (2002). Who follows whom? The impact of parties on media agenda formation in the 1997 British general election campaign. The Harvard International Journal of Press/Politics, 7(3), 34-54.

Brandenburg, H. (2005). Political bias in the Irish media: A quantitative study of campaign coverage during the 2002 general election. Irish Political Studies, 20(3), 297-322.

Braun, D., Hutter, S., \& Kerscher, A. (2015). What type of Europe ? The salience of European issues in EP elections reconsidered. Papier Für Die Konferenz "Die Politisierung Der EU-Demokratisierungspotenzial Oder Desin-Tegrationsgefahr?". Potsdam, Germany: Universität Potsdam.

Budge, I. (1982). Electoral volatility: Issue effects and basic change in 23 post-war democracies. Electoral Studies, 1(2), 147-168.

Carmines, E. G., \& Stimson, J. A. (1986). On the structure and sequence of issue evolution. The American Political Science Review, 80(3), 901-920.

Dalton, R. J., Beck, P. A., \& Huckfeldt, R. (1998). Partisan cues and the media: Information flows in the 1992 presidential election. The American Political Science Review, 92(1), 111-126.

de Lange, S. L., \& Art, D. (2011). Fortuyn versus Wilders: An Agency-based approach to radical right party building. West European Politics, 34(6), 1229-1249.

de Vreese, C. H. (2001). 'Europe' in the news a crossnational comparative study of the news coverage of key EU events. European Union Politics, 2(3), 283307. 
de Vries, C. E. (2007). Sleeping giant: Fact or fairytale? How European integration affects national elections. European Union Politics, 8(3), 363-385.

de Vries, C. E., \& Edwards, E. E. (2009). Taking Europe to its extremes: Extremist parties and public Euroscepticism. Party Politics, 15(1), 5-28.

De Wilde, P. (2010). How politicisation affects European integration. ARENA Report, 6(10).

De Wilde, P. (2011). No polity for old politics? A framework for analyzing the politicization of European integration. Journal of European Integration, 33(5), 559-575.

De Wilde, P., \& Zürn, M. (2012). Can the politicization of European integration be reversed? JCMS: Journal of Common Market Studies, 50, 137-153.

Dolezal, M., Ennser-Jedenastik, L., Müller, W. C., \& Winkler, A. K. (2014). How parties compete for votes: A test of saliency theory. European Journal of Political Research, 53(1), 57-76.

Ferrara, F., \& Weishaupt, J. T. (2004). Get your act together: Party performance in European Parliament elections. European Union Politics, 5(3), 283-306.

Galtung, J., \& Ruge, M. H. (1965). The structure of foreign news. The presentation of the Congo, Cuba and Cyprus crises in four Norwegian newspapers. Journal of Peace Research, 2(1), 65-91.

Green-Pedersen, C. (2012). A giant fast asleep? Party incentives and the politicisation of European integration. Political Studies, 60, 115-130.

Green-Pedersen, C., Mortensen, P. B., \& Thesen, G. (2015). The incumbency bonus revisited: Causes and consequences of media dominance. British Journal of Political Science.

Hallin, D. C., \& Mancini, P. (2004). Comparing media systems. Three models of media and politics. Cambridge: Cambridge University Press.

Hix, S., \& Marsh, M. (2007). Punishment or protest? Understanding European Parliament elections. The Journal of Politics, 69(2), 495-510.

Hobolt, S. B. (2014). A vote for the President? The role of Spitzenkandidaten in the 2014 European Parliament elections. Journal of European Public Policy, 21(10), 1528-1540.

Hobolt, S. B., \& de Vries, C. E. (2015). Issue entrepreneurship and multiparty competition. Comparative Political Studies, 48(9), 1159-1185.

Hobolt, S. B., Spoon, J.-J., \& Tilley, J. (2009). A vote against Europe?: Explaining defection at the 1999 and 2004 European Parliament elections. British Journal of Political Science, 39(1), 93-115.

Höglinger, D. (2012). Struggling with the intricate giant. How European integration is being politicized in Western Europe. Zurich, Switzerland: University of Zurich.

Hooghe, L., \& Marks, G. (2009). A postfunctionalist theory of European Integration: From permissive consensus to constraining dissensus. British Journal of Politi- cal Science, 39(1), 1-23.

Hopmann, D. N., de Vreese, C. H., \& Albaek, E. (2011). Incumbency bonus in election news coverage explained: The logics of political power and the media market. Journal of Communication, 61(2), 264-282.

Hopmann, D. N., Elmelund-Praestekaer, C., Albaek, E., Vliegenthart, R., \& de Vreese, C. H. (2012). Party media agenda-setting: How parties influence election news coverage. Party Politics, 18(2), 173-191.

Hopmann, D. N., Van Aelst, P., \& Legnante, G. (2012). Political balance in the news: A review of concepts, operationalizations and key finding. Journalism, 13(2), 240-257.

Hopmann, D. N., Vliegenthart, R., De Vreese, C. H., \& Albæk, E. (2010). Effects of election news coverage: How visibility and tone influence party choice. Political Communication, 27(4), 389-405.

Hutter, S., \& Grande, E. (2014). Politicizing Europe in the national electoral arena: A comparative analysis of five West European countries, 1970-2010. Journal of Common Market Studies, 52(5), 1007-1018.

Jalali, C., \& Silva, T. (2011). Everyone ignores Europe? Party campaigns and media coverage in the $2009 \mathrm{Eu}-$ ropean Parliament elections. In M. Maier, J. Strömbäck \& L. L. Kaid (Eds.), Political communication in European parliamentary elections (pp. 111 126). Farnham, UK: Ashgate.

Kleinnijenhuis, J., De Ridder, J. A., \& Rietberg, E. M. (1997). Reasoning in economic discourse. An application of the network approach to the Dutch press. In C. W. Roberts (Ed.), Text analysis for the social sciences. Methods for drawing statistical inferences from texts and transcripts (pp. 162-182). Mahwah: Lawrence Erlbaum Associates.

Koepke, J. R., \& Ringe, N. (2006). The second-order election model in an enlarged Europe. European Union Politics, 7(3), 321-346.

Koopmans, R. (2002). Codebook for the analysis of political mobilisation and communication in European public spheres. Retrieved from http://europub.wzb. eu/Data/Codebooksquestionnaires/D2-1-claims-code book.pdf

Koopmans, R. (2004). Movements and media: Selection processes and evolutionary dynamics in the public sphere. Theory and Society, 33(3/4), 367-391.

Koopmans, R., \& Muis, J. (2009). The rise of right-wing populist Pim Fortuyn in the Netherlands: A discursive opportunity approach. European Journal of Political Research, 48(5), 642-664.

Koopmans, R., \& Statham, P. (2010). Theoretical framework, research design, and methods. In R. Koopmans \& P. Statham (Eds.), The making of a European public sphere. Media discourse and political contention (pp. 34-59). Cambridge: Cambridge University Press.

Kriesi, H. (2007). The role of European integration in national election campaigns. European Union Politics, 8, 83-108. 
Kriesi, H., Grande, E., Dolezal, M., Helbling, M., Höglinger, D., Hutter, S., \& Wüest, B. (2012). Political conflict in Western Europe. Cambridge: Cambridge University Press.

Kriesi, H., Grande, E., Lachat, R., Dolezal, M., Bornschier, S., \& Frey, T. (2008). West European politics in the age of globalization. Cambridge: Cambridge University Press.

Long, J. S., \& Freese, J. (2001). Regression models for categorical dependent variables using Stata. College Station, TX: Stata Press.

Manin, B. (1997). The Principles of representative government. Cambridge: Cambridge University Press.

Marsh, M., \& Mikhaylov, S. (2010). European parliament elections and EU governance. Living Reviews in European Governance, 5, 1-30. Retrieved from http:// www.livingreviews.org/Ireg-2010-4

Mazzoleni, G. (2007). Populism and the media. In D. Albertazzi \& D. McDonnell (Eds.), Twenty-first century populism: The spectre of Western European democracy (pp. 49-64). Basingstoke: Palgrave Macmillan.

Mazzoleni, G., \& Schulz, W. (1999). "Mediatization" of politics: A Challenge for democracy? Political Communication, 16(3), 247-261.

McCombs, M., \& Shaw, D. L. (1972). The agenda-setting function of mass media. The Public Opinion Quarterly, 36(2), 176-187.

Meguid, B. M. (2005). Competition between unequals: The role of mainstream party strategy in niche party success. American Political Science Review, 99(03), 347-359.

Meijers, M. J. (2013). The Euro-crisis as a catalyst of the Europeanization of public spheres ? A cross-temporal study of the Netherlands and Germany (LSE "Europe in Question" Discussion Paper Series No.62/2013).

Meijers, M. J. (2015). Contagious Euroscepticism? The impact of Eurosceptic support on mainstream party positions on European integration. Party Politics, 111.

Rauh, C. (2015). Communicating supranational governance? The salience of EU affairs in the German Bundestag, 1991-2013. European Union Politics, 16(1), 116-138.

Rauh, C., \& Zürn, M. (2014). Zur politisierung der EU in der krise. In M. Heidenreich (Ed.), Krise der europäischen vergesellschaftung? Soziologische perspektiven (pp. 121-145). Wiesbaden, Germany: Springer VS.

Reif, K., \& Schmitt, H. (1980). Nine second-order national elections: A conceptual framework for the analysis of European election results. European Journal of Political Research, 8(1), 3-44.

Rittberger, B. (2012). Institutionalizing representative democracy in the European Union: The case of the European Parliament. Journal of Common Market Studies, 50(1), 18-37.

Rohrschneider, R., \& Clark, N. (2008). Second-order Elec- tions versus first-order thinking: How voters perceive the representation process in a multi-layered system of governance. In C. Van der Eijk \& H. Schmitt (Eds.), The multilevel electoral system of the EU (pp. 137162). Mannheim, Germany: CONNEX.

Schattschneider, E. E. (1960). The semisovereign people : A realist's view of democracy in America. New York: Holt, Rinehart and Winston.

Schmidt, V., \& Thatcher, M. (2013). Resilient liberalism in Europe's political economy. Cambridge: Cambridge University Press.

Schoenbach, K., De Ridder, J., \& Lauf, E. (2001). Politicians on TV news: Getting attention in Dutch and German election campaigns. European Journal of Political Research, 39(4), 519-531.

Senninger, R., \& Wagner, M. (2015). Political parties and the EU in national election campaigns: Who talks about Europe, and how? JCMS: Journal of Common Market Studies, 53(6), 1336-1351.

Statham, P., \& Trenz, H.-J. (2013). The politicization of Europe: Contesting the Constitution in the mass media. London: Routledge.

Strömbäck, J., Maier, M., \& Kaid, L. L. (2011). Political communication and election campaigns for the European Parliament. In M. Maier, J. Strömbäck, \& L. L. Kaid (Eds.), Political communication in European parliamentary elections (pp. 3-16). Farnham, UK: Ashgate.

Treib, O. (2014). The voter says no, but nobody listens: Causes and consequences of the Eurosceptic vote in the 2014 European elections. Journal of European Public Policy, 21(10), 1541-1554.

Tresch, A. (2009). Politicians in the media: Determinants of legislators' presence and prominence in Swiss newspapers. The International Journal of Press/ Politics, 14(1), 67-90.

Van de Wardt, M. (2015). Desperate needs, desperate deeds: Why mainstream parties respond to the issues of niche parties. West European Politics, 38(1), 93-122.

Van de Wardt, M., de Vries, C. E., \& Hobolt, S. B. (2014). Exploiting the cracks: Wedge issues in multiparty competition. The Journal of Politics, 76(04), 986-999.

Van der Brug, W., \& Van der Eijk, C. (Eds.). (2007). European elections \& domestic politics. Lessons from the past and scenarios for the future. Notre Dame, IN: University of Notre Dame Press.

Van der Eijk, C., \& Franklin, M. (2004). Potential for contestation on European matters at national elections in Europe. In G. Marks \& M. R. Steenbergen (Eds.), European integration and political conflict (pp. 3250). Cambridge: Cambridge University Press.

Van der Eijk, C., Franklin, M., \& Marsh, M. (1996). What voters teach us about Europe-wide elections: What Europe-wide elections teach us about voters. Electoral Studies, 15(2), 149-166.

Van Spanje, J. (2010). Contagious parties: Anti- 
immigration parties and their impact on other parties' immigration stances in contemporary Western Europe. Party Politics, 16(5), 563-586.

Van Spanje, J., \& de Vreese, C. H. (2014). Europhile media and Eurosceptic voting: Effects of news media coverage on Eurosceptic voting in the 2009 European parliamentary elections. Political Communication, 31(2), 325-354.

Vliegenthart, R., Boomgaarden, H. G., \& Van Spanje, J. (2012). Anti-immigrant party support and media visibility: A cross-party, over-time perspective. Journal of Elections, Public Opinion \& Parties, 22(3), 315-358.

Vliegenthart, R., Schuck, A. R. T., Boomgaarden, H. G., \& de Vreese, C. H. (2008). News coverage and support for European integration, 1990-2006. International Journal of Public Opinion Research, 20(4), 415-439.

Walgrave, S., \& De Swert, K. (2004). The making of the (issues of the) Vlaams Blok. Political Communication, 21(4), 479-500.

Walgrave, S., \& Van Aelst, P. (2006). The contingency of the mass media's political agenda setting power: Toward a preliminary theory. Journal of Communication, 56, 88-109.

Weaver, D., McCombs, M., \& Shaw, D. L. (2004). Agenda-setting research: Issues, attributes, and influences. In L. L. Kaid (Ed.), Handbook of political communication research (pp. 257-281). London: Lawrence Erlbaum Associates.

\section{About the Authors}

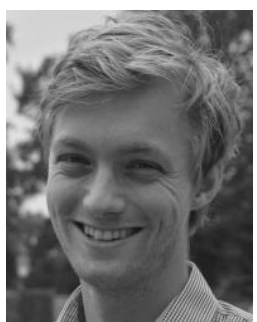

Maurits J. Meijers

Maurits J. Meijers is a doctoral researcher at the Hertie School of Governance Berlin in Germany. His research focuses on the patterns of interdependent party competition strategies in both domestic and supranational electoral and legislative settings. His doctoral dissertation expounds the ways in which Eurosceptic challenger parties affect mainstream party attitudes toward European integration. His publications include "Contagious Euroscepticism. The impact of Eurosceptic support on mainstream party positions on European integration" (Party Politics).

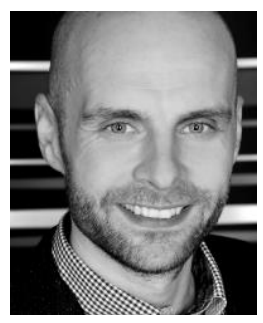

Dr. Christian Rauh

Christian Rauh is a fellow at the Global Governance Research Unit at the WZB Berlin Social Science Center. He writes and teaches on policy-making in the EU, the politicization of supra- and international decision-making, as well as on quantitative text analysis. Recent publications include "Communicating supranational governance? The salience of EU affairs in the German Bundestag, 19912013" (European Union Politics) and "A responsive technocracy? EU politicisation and the consumer policies of the European Commission" (ECPR Press, 2016). 
Appendix A1. Party identification dictionary.

Table A1.1. French keywords (names and individuals) for party identification.

\begin{tabular}{|c|c|c|c|}
\hline Group & Party names & Key individuals & Type of individual \\
\hline \multirow{24}{*}{ Centre Left } & Parti socialiste & Cambadélis & Leader (2014 only) \\
\hline & PS & Désir & Leader (2014 only) \\
\hline & & Aubry & Leader (2009 only) \\
\hline & & Ayrault & Incumbent (2014 only) \\
\hline & & Bricq & Incumbent (2014 only) \\
\hline & & Duflot & Incumbent (2014 only) \\
\hline & & Fabius & Incumbent (2014 only) \\
\hline & & Filippeti & Incumbent (2014 only) \\
\hline & & Fioraso & Incumbent (2014 only) \\
\hline & & Fourneyron & Incumbent (2014 only) \\
\hline & & Hollande & Incumbent (2014 only) \\
\hline & & Le Drian & Incumbent (2014 only) \\
\hline & & Le Foll & Incumbent (2014 only) \\
\hline & & Lebranchu & Incumbent (2014 only) \\
\hline & & Lurel & Incumbent (2014 only) \\
\hline & & Martin & Incumbent (2014 only) \\
\hline & & Montebourg & Incumbent (2014 only) \\
\hline & & Moscovici & Incumbent (2014 only) \\
\hline & & Pinel & Incumbent (2014 only) \\
\hline & & Sapin & Incumbent (2014 only) \\
\hline & & Taubira & Incumbent (2014 only) \\
\hline & & Touraine & Incumbent (2014 only) \\
\hline & & Vallaud-Belkacem & Incumbent (2014 only) \\
\hline & & Valls & Incumbent (2014 only) \\
\hline \multirow{15}{*}{$\begin{array}{l}\text { Centre } \\
\text { Right }\end{array}$} & UMP & Sarkozy & Leader / Incumbent \\
\hline & Union pour un mouvement populaire & Copé & Leader (2014 only) \\
\hline & & Bertrand & Leader (2009 only) \\
\hline & & Albanel & Incumbent (2009 only) \\
\hline & & Alliot-Marie & Incumbent (2009 only) \\
\hline & & Barnier & Incumbent (2009 only) \\
\hline & & Borloo & Incumbent (2009 only) \\
\hline & & Boutin & Incumbent (2009 only) \\
\hline & & Darcos & Incumbent (2009 only) \\
\hline & & Fillon & Incumbent (2009 only) \\
\hline & & Kouchner & Incumbent (2009 only) \\
\hline & & Lagarde & Incumbent (2009 only) \\
\hline & & Morin & Incumbent (2009 only) \\
\hline & & Pécresse & Incumbent (2009 only) \\
\hline & & Woerth & Incumbent (2009 only) \\
\hline \multirow{17}{*}{$\begin{array}{c}\text { Radical } \\
\text { Left }\end{array}$} & FdG & Laurent & Leader (2014 only) \\
\hline & FG & Buffet & Leader (2009 only) \\
\hline & Front de Gauche & Arthaud & Leader \\
\hline & Front de gauche pour changer d'Europe & Besancenot & Leader \\
\hline & Gauche Unitaire & Laguiller & Leader \\
\hline & GU & Mélenchon & Leader \\
\hline & LCR & Picquet & Leader \\
\hline & Ligue communiste révolutionnaire & Poupin & Leader \\
\hline & LO & & \\
\hline & Lutte $(\mathrm{O} \mid \mathrm{o})$ uvrière & & \\
\hline & Nouveau Parti anticapitaliste & & \\
\hline & NPA & & \\
\hline & Parti communiste français & & \\
\hline & Parti de Gauche & & \\
\hline & PCF & & \\
\hline & $P d G$ & & \\
\hline & PG & & \\
\hline \multirow{3}{*}{$\begin{array}{c}\text { Radical } \\
\text { Right }\end{array}$} & FN & Le Pen & Leader \\
\hline & Front National & & \\
\hline & FRONT NATIONAL & & \\
\hline
\end{tabular}


Table A1.2. Dutch keywords (names and individuals) for party identification.

\begin{tabular}{|c|c|c|c|}
\hline Group & Party names & Key individuals & Type of individual \\
\hline \multirow{14}{*}{ Center Left } & Partij van de Arbeid & Samsom & Leader (2014 only) \\
\hline & PvdA & Spekman & Leader (2014 only) \\
\hline & & Bos & Leader (2009 only) \\
\hline & & Asscher & Incumbent (2014 only) \\
\hline & & Bussemaker & Incumbent (2014 only) \\
\hline & & Dijsselbloem & Incumbent (2014 only) \\
\hline & & Plasterk & Incumbent (2014 only) \\
\hline & & Ploumen & Incumbent (2014 only) \\
\hline & & Timmermans & Incumbent (2014 only) \\
\hline & & Cramer & Incumbent (2009 only) \\
\hline & & Koenders & Incumbent (2009 only) \\
\hline & & Plasterk & Incumbent (2009 only) \\
\hline & & ter Horst & Incumbent (2009 only) \\
\hline & & van der Laan & Incumbent (2009 only) \\
\hline \multirow{16}{*}{ Center Right } & Christen-Democratisch Appèl & Bruma & Leader (2014 only) \\
\hline & CDA & Balkenende & Leader (2009 only) \\
\hline & & Verhagen & Incumbent (2009 only) \\
\hline & & Hirsch Ballin & Incumbent (2009 only) \\
\hline & & Eurlings & Incumbent (2009 only) \\
\hline & & van der Hoeven & Incumbent (2009 only) \\
\hline & & Verburg & Incumbent (2009 only) \\
\hline & & Donner & Incumbent (2009 only) \\
\hline & & Klink & Incumbent (2009 only) \\
\hline & Volkspartij voor Vrijheid en Democratie & Rutte & Leader \\
\hline & VVD & Kamp & Incumbent (2014 only) \\
\hline & & Hennis-Plasschaert & Incumbent (2014 only) \\
\hline & & Schippers & Incumbent (2014 only) \\
\hline & & Schultz van Haegen & Incumbent (2014 only) \\
\hline & & Blok & Incumbent (2014 only) \\
\hline & & Opstelten & Incumbent (2014 only) \\
\hline \multirow{2}{*}{ Radical Left } & Socialistische Partij & Marijnissen & Leader (2009 only) \\
\hline & SP & Roemer & Leader (2014 only) \\
\hline Radical Right & $\begin{array}{l}\text { Partij voor de Vrijheid } \\
\text { PVV }\end{array}$ & Wilders & Leader \\
\hline
\end{tabular}


Appendix A2. European integration dictionaries.

Table A2.1. French keywords marking European integration issues.

\begin{tabular}{|c|c|c|c|}
\hline les européennes & Banque centrale européenne & $\begin{array}{l}\text { ([[:alpha:]])*avis } \\
\text { europée([[:alpha:]])* }\end{array}$ & $\begin{array}{l}\text { mesur([[:alpha:]])* } \\
\text { européen([[:alpha:]])* }\end{array}$ \\
\hline $\begin{array}{l}\text { électio([[:alpha:]])* au parlement } \\
\text { européen }\end{array}$ & BCE & $\begin{array}{l}\text { affaire }([[: \text { alpha:]])* } \\
\text { européen([[:alpha:]])* }\end{array}$ & monnaie commune \\
\hline $\begin{array}{l}\text { électio([[:alpha:]])* } \\
\text { européen }([[: a l p h a:]])^{*}\end{array}$ & budget de l'Union européenne & agenda européen & $\begin{array}{l}\text { norme }([[: a l p h a:]])^{*} \\
\text { européen([[:alpha:]])* }\end{array}$ \\
\hline scruti $([[: \text { alpha: }]])^{*}$ & CJCE & avis de l'ue & orientatio([[:alpha:]])* de l'UE \\
\hline & CJUE & budget de l'UE & $\begin{array}{l}\text { orientatio([[:alpha:]])* } \\
\text { europée([[:alpha:]])* }\end{array}$ \\
\hline commissaire de I'UE & Commission européenne & compétenc([[:alpha:]])* de l'UE & Pacte de stabilité et de croissance \\
\hline $\begin{array}{l}\text { Commissaire } \\
\text { européen([[:alpha:]])\{0,1\} }\end{array}$ & Conseil européen & $\begin{array}{l}\text { compétenc([[:alpha:]])* } \\
\text { europée([[:alpha:]])* }\end{array}$ & politique de I'UE \\
\hline conseil des ministres européen & $\begin{array}{l}\text { Cour de justice de l'Union } \\
\text { européenne }\end{array}$ & crise de la dette & politique de l'Union européenne \\
\hline $\begin{array}{l}\text { déput([[:alpha:]])* au Parlement } \\
\text { européen }\end{array}$ & $\begin{array}{l}\text { Cour de justice des Communautés } \\
\text { européennes }\end{array}$ & crise de l'euro & $\begin{array}{l}\text { politique étrangère et de sécurité } \\
\text { commune }\end{array}$ \\
\hline députe au Parlement européen & cour de justice européenne & décisio([[:alpha:]])* de l'ue & $\begin{array}{l}\text { politique étrangère et de sécurité } \\
\text { européenne }\end{array}$ \\
\hline députe europée([[:alpha:]])* & Cour des comptes européenne & $\begin{array}{l}\text { décisio([[:alpha:]])* } \\
\text { europée([[:alpha:]])* }\end{array}$ & politique européenne \\
\hline eurodépute & eta([[:alpha:]])* de l'ue & Directiv([[:alpha:]])* de l'UE & $\begin{array}{l}\text { procedur }([[: a l p h a:]])^{*} \\
\text { europée([[:alpha:]])* }\end{array}$ \\
\hline MPE & $\begin{array}{l}\text { etat }([[: a l p h a:]])^{*} \\
\text { membre([[:alpha:]])* de l'UE }\end{array}$ & Directive de l'Union européenne & programme européen \\
\hline Parlement européen & $\begin{array}{l}\text { etat }([[: a l p h a:]])^{*} \\
\text { membre([[:alpha:]])* de l'Union } \\
\text { européenne }\end{array}$ & droit de l'ue & $\begin{array}{l}\text { recommandatio([[:alpha:]])* de } \\
\text { I'ue }\end{array}$ \\
\hline président de la Commission & eurogroupe & droit de l'union européenne & $\begin{array}{l}\text { recommandatio([[:alpha:]] })^{*} \\
\text { europée([[:alpha:]])* }\end{array}$ \\
\hline $\begin{array}{l}\text { président de la Banque centrale } \\
\text { européenne }\end{array}$ & $\begin{array}{l}\text { executi([[:alpha:]])* } \\
\text { europée }([[: a l p h a:]])^{*}\end{array}$ & droit européen & $\begin{array}{l}\text { règle }([[: a l p h a:]])^{*} \\
\text { européen([[:alpha:]] })^{*}\end{array}$ \\
\hline Président du Conseil européen & FEDER & $\begin{array}{l}\text { engagement }([[: \text { alpha: }]])^{*} \\
\text { européen }([[: \text { alpha: }]])^{*}\end{array}$ & règlemen([[:alpha:]])* de l'ue \\
\hline & fonctionnair([[:alpha:]])* de l'ue & $\begin{array}{l}\text { fonds ([[:alpha:]])*( } \\
)^{*} \text { europé([[:alpha:]])* }\end{array}$ & $\begin{array}{l}\text { règlemen }([[: \text { alpha:]])* } \\
\text { europée }([[: \text { alpha:]])* }\end{array}$ \\
\hline coopération européenne & $\begin{array}{l}\text { Fonds européen de } \\
\text { développement régional }\end{array}$ & juridique de I'UE & Schengen \\
\hline intégration européenne & Fonds social européen & juridique europée([[:alpha:]])* & $\begin{array}{l}\text { stratégi }([[: \text { alpha:]])* } \\
\text { europée }([[: a l p h a:]])^{*}\end{array}$ \\
\hline projet européen & FSE & l'euro & stratégie de l'UE \\
\hline traité d'Amsterdam & $\begin{array}{l}\text { Haut-Représentan([[:alpha:]])* } \\
\text { institutio([[:alpha:]])* de l'ue }\end{array}$ & $\begin{array}{l}\text { législat([[:alpha:]])* de l'UE } \\
\text { législat([[:alpha:]])* } \\
\text { europée([[:alpha:]])* }\end{array}$ & $\begin{array}{l}\text { subside }([[: \text { alpha: }]])^{*} \text { de l'ue } \\
\text { subside([[:alpha:]] })^{*} \\
\text { europée([[:alpha:]])* }\end{array}$ \\
\hline constitution européenne & $\begin{array}{l}\text { institutio([[:alpha:]])* } \\
\text { européen([[:alpha:]])* }\end{array}$ & lo([[:alpha:]])* de l'ue & subvention([[:alpha:]])* de l'ue \\
\hline $\begin{array}{l}\text { fonctionnair([[:alpha:]])* } \\
\text { europée }([[: a l p h a:]])^{*}\end{array}$ & $\operatorname{organ}([[: a l p h a:]]) *$ de l'UE & $\begin{array}{l}\text { lo([[:alpha:]])* } \\
\text { europée([[:alpha:]])* }\end{array}$ & $\begin{array}{l}\text { subvention }([[: a l p h a:]])^{*} \\
\text { europée([[:alpha:]])* }\end{array}$ \\
\hline TCE & $\begin{array}{l}\text { organ([[:alpha:]])* } \\
\text { européen([[:alpha:]])* }\end{array}$ & Mandat europé([[:alpha:]])* & \\
\hline TECE & Parlement européen & & \\
\hline trait([[:alpha:]])* de l'UE & pays de l'ue & marché intérieur de l'UE & \\
\hline $\begin{array}{l}\text { trait([[:alpha:]])* de l'Union } \\
\text { européenne }\end{array}$ & sommet européen & $\begin{array}{l}\text { marché intérieur de l'Union } \\
\text { européene }\end{array}$ & \\
\hline $\begin{array}{l}\text { trait([[:alpha:]])* } \\
\text { europée([[:alpha:]])* }\end{array}$ & UEM & marché intérieur européen & \\
\hline traité de Lisbonne & Union économique et monétaire & marché unique européen & \\
\hline traité de Lisbonne & Union européenne & marché unique de l'UE & \\
\hline traité de Maastricht & union monétaire & $\begin{array}{l}\text { marché unique de l'Union } \\
\text { européene }\end{array}$ & \\
\hline $\begin{array}{l}\text { traité de Nice } \\
\text { traite de Rome de } 2004 \\
\text { traite de Rome II } \\
\text { traite établissant une constitution } \\
\text { pour l'Europe } \\
\text { traité sur l'UE } \\
\text { traité sur l'Union européenne }\end{array}$ & zone euro & & \\
\hline
\end{tabular}


Table A2.2. Dutch keywords marking European integration issues.

\begin{tabular}{|c|c|c|c|}
\hline $\begin{array}{l}\text { (E|e)uropese verkiezingen } \\
\text { verkiezingen voor het }\end{array}$ & $\begin{array}{l}\text { (E|e)uropese } \\
\text { lidsta([[:alpha:]])* }\end{array}$ & (EU|eu)-richtlijn([[:alpha:]])* & $\begin{array}{l}\text { (E)e)uropese } \\
\text { aanbeveling([[:alpha:]])* }\end{array}$ \\
\hline $\begin{array}{l}\text { (E|e)uropees Parlement } \\
\text { (E)e)uropese }\end{array}$ & (EU|eu)-lidsta([[:alpha:]])* & $\begin{array}{l}\text { (E|e)uropese regel([[:alpha:]])* } \\
\text { (E|e)uropese }\end{array}$ & $\begin{array}{l}\text { (EU|eu)-advie([[:alpha:]])* } \\
\text { (E|e)urope([[:alpha:]])* }\end{array}$ \\
\hline Parlementsverkiezingen & $\begin{array}{l}\text { (E|e)uropese Unie } \\
\text { (E|e)uropese Commissie }\end{array}$ & (EU|eu)-begroting & $\begin{array}{l}\text { advie([[:alpha:]])* } \\
\text { (E|e)uropese } \\
\text { beleidslijn([[:alpha:]])* }\end{array}$ \\
\hline (ecb|ECB)-directie & (E|e)uropees Parlement & (E|e)uropese begroting & $\begin{array}{l}\text { (EU|eu)-beleidslijn([[:alpha:]])* } \\
\text { (E|e)uropese }\end{array}$ \\
\hline commissievoorzitter & $\begin{array}{l}\text { (E|e)uropese Raad } \\
\text { Hof van Justitie van de }\end{array}$ & Schengen & $\begin{array}{l}\text { competentie([[:alpha:]])* } \\
\text { (EU|eu)- }\end{array}$ \\
\hline (E|e)uropese ministerraad & (E|e)uropese Unie & de (E|e)uro & competentie([[:alpha:]])* \\
\hline $\begin{array}{l}\text { Raad van Ministers } \\
\text { voorzitter van de (E|e)uropese }\end{array}$ & (E|e)uropees Hof van Justitie & (E|e)uropese grondwet & (E|e)uropese rechtsorde \\
\hline Centrale Bank & $\begin{array}{l}\text { (E|e)uropese Rekenkamer } \\
\text { ECB }\end{array}$ & $\begin{array}{l}\text { schuldencrisis } \\
(E \mid e) \text { uropese }\end{array}$ & $\begin{array}{l}\text { (EU|eu)-rechtsorde } \\
\text { (E|e)uropese } \\
\text { strategi([[:alpha:]])* }\end{array}$ \\
\hline (E|e)uropese commissaris & $\begin{array}{l}\text { (E|e)uropese Centrale Bank } \\
\text { (E|e)uropees Fonds voor }\end{array}$ & instelling([[:alpha:]])* & (EU|eu)-strategi([[:alpha:]])* \\
\hline Eurocommissaris & Regionale Ontwikkeling & (EU|eu)-instelling([[:alpha:]])* & (EU|eu)-verdrag([[:alpha:]])* \\
\hline EU commissaris & EFRO & (EU|eu)-organen & (E|e)uropese politiek \\
\hline (EU|eu)-parlementariër & (E|e)uropees Sociaal Fonds & $\begin{array}{l}\text { (E|e)uropees orgaan } \\
(E \mid e) \text { uropese }\end{array}$ & (EU|eu)-politiek \\
\hline Europarlementariër & ESF & maatregel([[:alpha:]])* & $\begin{array}{l}\text { (E|e)uropese binnenmarkt } \\
\text { (E|e)urope([[:alpha:]])* }\end{array}$ \\
\hline $\begin{array}{l}\text { (E|e)uropese raadsvoorzitter } \\
\text { Voorzitter van de (E|e)uropese }\end{array}$ & Euro zone & $\begin{array}{l}\text { (EU|eu)-maatregel([[:alpha:]])* } \\
\text { (E|e)urope([[:alpha:]])* }\end{array}$ & programm([[:alpha:]])* \\
\hline \multirow[t]{2}{*}{ Raad } & Eurozone & Manda([[:alpha:]])* & $\begin{array}{l}\text { (EU|eu)-subsidi([[:alpha:]])* } \\
\text { (E|e)uropese }\end{array}$ \\
\hline & $\begin{array}{l}\text { stabiliteits- en groeipact } \\
\text { EU ([[:alpha:]])*( }\end{array}$ & EU manda([[:alpha:]])* & $\begin{array}{l}\text { subsidi([[:alpha:]])* } \\
\text { gemeenschappelijk buitenlands }\end{array}$ \\
\hline verdrag([[:alpha:]])* & $\begin{array}{l}\text { )*fonds([[:alpha:]])* } \\
\text { (E|e)urope([[:alpha:]])* }\end{array}$ & (E|e)uropese top & $\begin{array}{l}\text { en veiligheidsbeleid } \\
(E \mid e) \text { uropees buitenlands en }\end{array}$ \\
\hline Verdrag van Maastricht & fond([[:alpha:]])* & EU top & $\begin{array}{l}\text { veiligheidsbeleid } \\
\text { (EU|eu)- }\end{array}$ \\
\hline Verdrag van Amsterdam & structuurfond([[:alpha:]])* & (E|e)urogroep & $\begin{array}{l}\text { voorschrift([[:alpha:]])* } \\
\text { Europe([[:alpha:]])* }\end{array}$ \\
\hline Verdrag van Nice & monetaire unie & (E|e)uropees recht & $\begin{array}{l}\text { Voorschrift([[:alpha:]])* } \\
\text { (E|e)uropese }\end{array}$ \\
\hline $\begin{array}{l}\text { Verdrag van Lissabon } \\
\text { (E|e)uropese }\end{array}$ & gemeenschappelijke munt & (EU|eu)-recht([[:alpha:]])* & norm([[:alpha:]])* \\
\hline \multirow[t]{2}{*}{ ambtena([[:alpha:]])* } & (EU|eu)-orgaan & (EU|eu)-wetgeving & EU norm([[:alpha:]])* \\
\hline & (E|e)uropese organen & (E|e)uropese wetgeving & (E|e)uropese betrokkenheid \\
\hline (E|e)uropese integratie & (EU|eu)-ambtena([[:alpha:]])* & (EU|eu)-wet & EU betrokkenheid \\
\hline (E|e)uropese samenwerking & hoge vertegenwoordiger & (E|e)uropese wet([[:alpha:]])* & \\
\hline \multirow[t]{7}{*}{ (E|e)uropese executieve } & (E|e)uropese project & (EU|eu)-regelgeving & \\
\hline & (EU|eu)-land([[:alpha:]])* & (E|e)uropese regelgeving & \\
\hline & $\begin{array}{l}\text { (EU|eu)-sta([[:alpha:]])* } \\
\text { (E|e)uropees Hof van Justitie }\end{array}$ & $\begin{array}{l}\text { (EU |eu)-regel([[:alpha:]])* } \\
\text { (E|e)urope }([[: a l p h a:]])^{*} \\
\text { besluit }([[: a l p h a:]])^{*}\end{array}$ & \\
\hline & $\begin{array}{l}\text { (EU|eu)-gerechtshof } \\
\text { (E|e)uropese } \\
\text { procedur([[:alpha:]])* }\end{array}$ & $\begin{array}{l}\text { (EU|eu)-besluit([[:alpha:]])* } \\
\text { (E|e)uropese } \\
\text { beschikking([[:alpha:]])* }\end{array}$ & \\
\hline & (E|e)uropese interne markt & $\begin{array}{l}\text { (EU|eu)-beschikking } \\
\text { (E|e)uropese }\end{array}$ & \\
\hline & (E|e)uropese eenheidsmarkt & verordening([[:alpha:]])* & \\
\hline & (E|e)uropese agenda & (EU|eu)-verordening & \\
\hline
\end{tabular}


Appendix A3. Comparison automated and manual coding.

To validate our automated measure of mediatized partisan mobilization presented in Section four of the article, this appendix compares it to a set of hand-coded data gathered by the first author in an earlier project on the 2014 EP elections in France and the Netherlands. Here a human coder identified acts of partisan mobilization in newspaper articles along the nuclear sentence approach (Kleinnijenhuis, De Ridder, \& Rietberg, 1997). This is very close, but not identical to the aims of the measure proposed in this article. First, the manually coded data only capture direct, literal party statements whereas our data also includes journalistic attributions. Second, the manually coded data rely on slightly different newspaper samples excluding L'Humanité for France but including NRC Handelsblad and Het Financieele Dagblad for the Netherlands.

Thus, the human coded data present a more conservative measure of partisan mobilization on the one hand and may be subject to different newspaper biases on the other. But if our claim is correct that our automated measure by and large captures partisan efforts to mobilize on Europe, they should be systematically related to the event counts retrieved by this human data collection. We thus merged both data sets for the overlapping 396 daily observations during the 2014 EP election campaign to compare the results.

Figure A3.1 plots the linear relationships between the automated and the manually coded counts. Specifically, the graph shows the relationship between the daily counts of articles containing automatically retrieved co-occurrences of political party and EU keywords and the daily count of articles containing manually coded party statements on European integration. In fact, our counts are on average somewhat higher as assumed above. But across countries and also across party groups they are positively and significantly related to the manually coded information. This does not fully hold for the radical left in France which has a limited number of observations in both data sets: the relationship is still positive but closely fails to reach conventional levels of statistical significance. Yet, all in all these findings make us even more confident that our measures tap into the dynamics we are interested in.

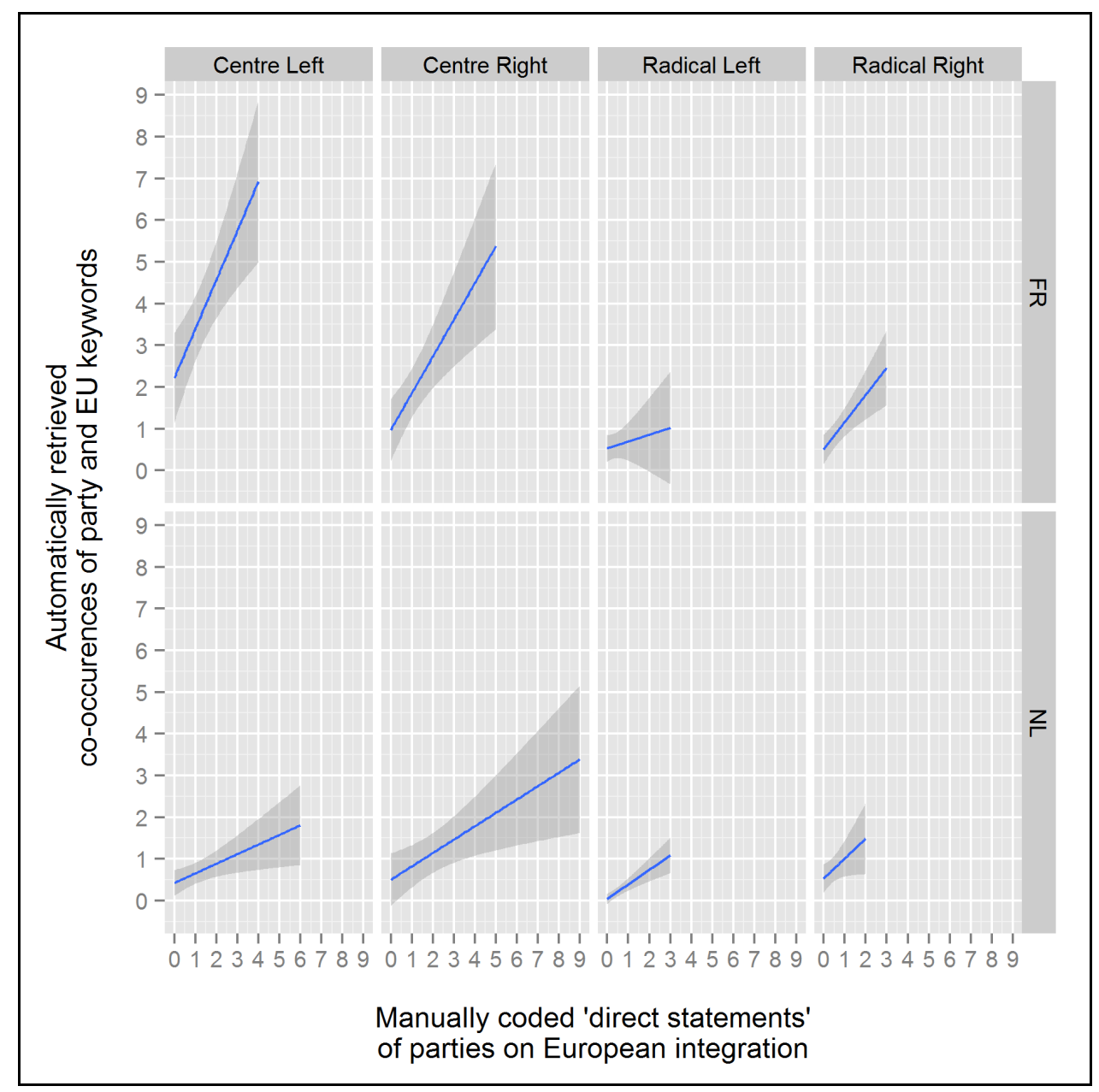

Figure A3.1. Comparing automated and manual coding in the 2014 EP elections. Note: The graph plots the linear correlation between the daily counts of articles containing automatically retrieved co-occurrences of political party and EU keywords and the daily count of articles containing manually coded party statements on European integration. 
Appendix A4. Descriptive statistics.

The descriptive statistics used to calculate Figure 1 in the article, which plots the average daily co-occurrences of party groups and European issues, are presented in Table A4.1. To be sure, Figure 1 in the article shows the daily main of cooccurrences of party groups and European issues, whereas Table A4.1 shows the sum of all co-occurrences of party groups and European issues per party for each country/election.

Table A4.1. Descriptive statistics of party and EU keyword co-occurrences at article level.

\begin{tabular}{lccccc}
\hline & \multicolumn{3}{c}{ France } & & \multicolumn{2}{c}{ The Netherlands } \\
\cline { 2 - 3 } \cline { 5 - 6 } & $\mathbf{2 0 0 9}$ & $\mathbf{2 0 1 4}$ & 388 & $\mathbf{2 0 0 9}$ & $\mathbf{2 0 1 4}$ \\
\hline Centre-Right & 920 & 732 & $150 / 110$ & $65 / 170$ \\
Centre-Left & 284 & 192 & 115 & 140 \\
Radical Right & 16 & 128 & 55 & 150 \\
Radical Left & 104 & 1440 & 50 & 35 \\
N & 1324 & 480 & 560 \\
\hline
\end{tabular}

Note: Table shows the total number of articles with co-occurrences of party keywords with EU keywords in the same grammatical sentence. The centre-right category for the Netherlands comprises both centre-right parties and first reports CDA results followed by the VVD results (CDA/VVD).

Table A4.2 shows a tabulation of the descriptive statistics of the dependent variable of the negative binomial panel regression models (see Table 2 in the article). The table shows that we are dealing with highly over-dispersed dataindicated by the fact that the variance of the count variables is greater than their mean.

Table A4.2. Descriptive statistics of the dependent variable.

\begin{tabular}{|c|c|c|c|c|}
\hline & \multicolumn{2}{|c|}{ France } & \multicolumn{2}{|c|}{ The Netherlands } \\
\hline & 2009 & 2014 & 2009 & 2014 \\
\hline Mean & 3.01 & 2.8 & 0.58 & 0.58 \\
\hline Variance & 9.42 & 9.09 & 1.07 & 1.04 \\
\hline $\mathrm{N}$ & 100 & 100 & 129 & 129 \\
\hline
\end{tabular}

Note: Table shows the mean and the variance for the dependent variable in the negative binomial panel regression models, i.e. the number of co-occurrences of party and EU keywords per day for the mainstream parties. 
Appendix A5. Robustness check.

The models in the main article are negative binomial regression models calculated with random effects. The decision to opt for random effects models rather than fixed effects models was informed by our substantive interest to include an incumbent dummy in the models. Since we have a low number of panels in both cases, this would result in perfect and near multicollinearity of the models in the French and Dutch cases respectively. To ensure that our models are robust to more stringent, fixed effects specification, we have re-calculated the models with party fixed effects, which limit the calculated variation to within party variation only. These models are shown in Table A5.1 and do lead to the same substantial interpretations presented in the main text of the article.

Table A5.1. Negative binomial panel regression results.

\begin{tabular}{|c|c|c|c|c|}
\hline & \multicolumn{4}{|c|}{ Daily co-occurrences of Mainstream parties and EU issues } \\
\hline & \multicolumn{2}{|c|}{ France } & \multicolumn{2}{|c|}{ The Netherlands } \\
\hline & 2009 & 2014 & 2009 & 2014 \\
\hline & Model 1 & Model 2 & Model 3 & Model 4 \\
\hline \multirow[t]{2}{*}{ Lagged DV (t-1) } & 1.031 & $1.057^{+}$ & 0.837 & 1.081 \\
\hline & $(0.0307)$ & $(0.0312)$ & $(0.164)$ & $(0.110)$ \\
\hline \multirow[t]{2}{*}{ EU Statements Rad. Left (t-1) } & 1.172 & $1.140^{*}$ & 0.635 & 1.194 \\
\hline & $(0.118)$ & $(0.0682)$ & $(0.245)$ & $(0.346)$ \\
\hline \multirow[t]{2}{*}{ EU Statements Rad. Right (t-1) } & $2.303^{* *}$ & $1.159^{*}$ & $2.210^{*}$ & $1.375^{*}$ \\
\hline & $(0.522)$ & (0.0788) & $(0.723)$ & $(0.178)$ \\
\hline \multirow[t]{2}{*}{ Constant } & $2.470^{*}$ & 1.375 & 0.585 & 0.944 \\
\hline & $(0.953)$ & $(0.415)$ & $(0.232)$ & $(0.489)$ \\
\hline No. observations & 98 & 98 & 126 & 126 \\
\hline No. of Days & 49 & 49 & 42 & 42 \\
\hline Wald $\mathrm{Chi}^{2}$ & $17.44^{* *}$ & $31.93 * *$ & $7.0^{+}$ & $9.73^{+}$ \\
\hline Log likelihood & -190.89 & -192.87 & -119.66 & -116.04 \\
\hline
\end{tabular}

Notes: Exponentiated coefficients (Incidence rate ratios); Standard errors in parentheses; Model includes party fixed effects (not shown); ${ }^{+} p<0.10,{ }^{*} p<0.05,{ }^{* *} p<0.01$. 
Appendix A6. Reverse models.

With regard to the interaction between party campaigning, the substantive focus of this article is on the impact of Eurosceptic challenger parties' visible mobilization efforts on the visibility mainstream party mobilization. Table A6.1 nevertheless shows the estimates of the reverse model: whether visible mainstream party mobilization on EU issues affects the extent to which Eurosceptic challenger parties visibly address European issues. Unlike the main models presented in Table 2 and Table A5.1, not all reverse models are significant. Only the 2014 models for both countries have significant Wald $\mathrm{Chi}^{2}$ estimates-indicating overall model significance. Looking at the French model for the 2014 EP campaign, it becomes apparent that visible mainstream party EU mobilization efforts do not affect the degree of visible mobilization efforts of the Eurosceptic challenger parties. In the Dutch 2014 EP campaign, we do find significant effects. Both the statement by the Dutch centre-left and by the centre-right party VVD affect the extent to which Eurosceptic parties visibly emphasize EU issues in the written news media.

Table A6.1. Reverse negative binomial panel regression results.

\begin{tabular}{|c|c|c|c|c|c|c|c|c|}
\hline & \multicolumn{8}{|c|}{ Daily co-occurrences of Eurosceptic challenger parties and EU issues } \\
\hline & \multicolumn{4}{|c|}{ France } & \multicolumn{4}{|c|}{ The Netherlands } \\
\hline & \multicolumn{2}{|c|}{$\begin{array}{c}2009 \\
\text { Model } 1\end{array}$} & \multicolumn{2}{|c|}{$\begin{array}{c}2014 \\
\text { Model } 2\end{array}$} & \multicolumn{2}{|c|}{$\begin{array}{c}2009 \\
\text { Model } 3\end{array}$} & \multicolumn{2}{|c|}{$\begin{array}{c}2014 \\
\text { Model } 4\end{array}$} \\
\hline & Coef. & IRR & Coef. & IRR & Coef. & IRR & Coef. & IRR \\
\hline Lagged DV (t-1) & $\begin{array}{c}0.0992 \\
(0.0716)\end{array}$ & 1.104 & $\begin{array}{r}0.0708 \\
(0.0502)\end{array}$ & 1.073 & $\begin{array}{c}0.240 \\
(0.533)\end{array}$ & 1.272 & $\begin{array}{l}-0.0346 \\
(0.233)\end{array}$ & 0.966 \\
\hline EU Statements Centre Left (t-1) & $\begin{array}{l}-0.0402 \\
(0.0615)\end{array}$ & 0.961 & $\begin{array}{r}0.0295 \\
(0.0389)\end{array}$ & 1.030 & $\begin{array}{r}-0.0463 \\
(0.513)\end{array}$ & 0.955 & $\begin{array}{c}0.430^{*} \\
(0.206)\end{array}$ & 1.537 \\
\hline EU Statements Centre Right (t-1) & $\begin{array}{l}-0.0348 \\
(0.0622)\end{array}$ & 0.966 & $\begin{array}{r}0.0224 \\
(0.0440)\end{array}$ & 1.023 & & & & \\
\hline $\begin{array}{l}\text { EU Statements } \\
\text { CDA }(\mathrm{t}-1)\end{array}$ & & & & & $\begin{array}{r}-0.0446 \\
(0.262)\end{array}$ & 0.956 & $\begin{array}{l}-0.0273 \\
(0.331)\end{array}$ & 0.973 \\
\hline EU Statements & & & & & -0.121 & 0.886 & $0.182^{+}$ & 1.200 \\
\hline $\operatorname{VVD}(\mathrm{t}-1)$ & & & & & $(0.415)$ & & (0.100) & \\
\hline Constant & $\begin{array}{r}0.716^{*} \\
(0.324)\end{array}$ & & $\begin{array}{c}0.268 \\
(0.295)\end{array}$ & & $\begin{array}{c}14.53 \\
(1971.9)\end{array}$ & & $\begin{array}{c}-0.000390 \\
(0.935)\end{array}$ & \\
\hline No. obs. & 98 & & 98 & & 8 & & 84 & \\
\hline No. of Days & 49 & & 49 & & 42 & & 42 & \\
\hline Wald $\mathrm{Chi}^{2}$ & 3.92 & & 23.3 & & 0.4 & & 9.63 & \\
\hline Log likelihood & -195.85 & & -195 & & -43 & & -59.8 & \\
\hline
\end{tabular}

Notes: Coefficients and exponentiated coefficients (IRRs) shown; Standard errors in parentheses; Model includes party fixed effects (not shown); $+p<0.10, * p<0.05, * * p<0.01$ 